\title{
Multicultural Education in the Globalization Era: Challenges and Expectations
}

\author{
${ }^{1}$ Apeles Lexi Lonto* \\ Pancasila and Civic Education \\ Department \\ Faculty of Social Sciences \\ Universitas Negeri Manado \\ Tondano, Indonesia \\ lexi.lontoh@unima.ac.id
}

\author{
${ }^{2}$ Ruth Sriana Umbase \\ Social Studies Education Study \\ Program \\ Faculty of Social Sciences \\ Universitas Negeri Manado \\ Tondano, Indonesia \\ ruthumbase@unima.ac.id
}

\begin{abstract}
The challenges faced in organizing multicultural education in Indonesia in the current era of globalization are very complex, interrelational and interdependent. Practically whether the concepts and approaches that have been applied in educational units or institutions are still relevant to an increasingly dynamic and uncertain era. The challenges of monoculture guided by the globalization of communication and information have given rise to new ideas for the integration and adaptation of global culture. However, there are also new hopes to renew and strengthen concepts and approaches in multicultural education for the future of the implementation of education in Indonesia so that it is relevant to maximize the potential of students so that they are skilled in responding to changes that take place in a revolutionary way.
\end{abstract}

Keywords: Relevance, Multicultural Education, Challenges, Era of Globalization

\section{INTRODUCTION}

The implementation of multicultural education in Indonesia is considered relevant to the conditions of Indonesian people who have a diversity and complexity of culture. Recognition of various cultures owned by Indonesian people is the main key to respecting the cultural diversity.

Learners from the beginning are expected to have an understanding that every human being has the right to live in a variety of unique ways in accordance with their respective cultural patterns. This understanding then has implications for the formation of mindset, positive attitudes and appropriate actions in providing recognition and appreciation for the existence of cultural diversity in Indonesia, even the world community. Likewise educators are expected to be able to meet the learning needs of students in accordance with these expectations. Under normal conditions, all of that can take place normatively according to the applicable curriculum content. But the changing global conditions that are taking place rapidly through the revolution in the field of information and communication technology have had a wide-ranging impact in various fields including meeting the learning needs of students.
Multicultural education is rooted in the view "Multiculturalism". Reference [1] states that "Multiculturalism is not an easy notion, it contains a very complex understanding of" multi "which means plural, and" culturalism "which contains a notion of culture or culture. The term plural means various types, why? because pluralism does not mean merely recognition of the kinds of things but also recognition has political, social and economic implications.

Politically, pluralism is related to the principles of democracy, socially related to the diversity of society both in terms of social strata and diversity in social institutions including educational institutions [2]. Furthermore, in the economic field associated with the birth of economic ideas and behavior about capitalism and neo-capitalism that colors free trade, free markets, multinational corporations, and others. This linkage also presents strengths in diversity as well as weaknesses in diversity.

Associated with the development of the power of cultural pluralism through "multicultural education instruments" that seek to establish "common ground" in cultural diversity, diversity can be a strength that strengthens the unity of a nation but can also be a weakness that can create disintegration of a nation. The role of education is very strategic in maximizing each of its strengths and also eliminating any of its weaknesses.

In the context of globalization, the idea of national unity began to be directed towards the idea of international unity. From an economic standpoint, the emergence of multinational companies and the active role of interest groups in the United States have urged governments in these countries to get involved in international affairs after the First World War in order to secure their global economic interests. The establishment of the United Nations on October 24, 1945 in San Francisco California has encouraged international cooperation in various fields. Until now the existence of fifteen United Nations Special Bodies (Organizations) has played an important role in establishing cooperation 
in various fields. The world is being brought into a new order called cooperation that means engagement to realize the Sustainable Development Goals initiated by the United Nations and operated by the United Nations Special Organizations.

The sophistication of information and communication technology further strengthens international cooperation but also contributes to friction in the competition for global economic influence. Changes that occur in the digital age also have implications for changes in the culture of the community. Communities are faced with two types of poles of culture namely open culture or closed culture with a series of positive and negative impacts.

The fact of transmission - the spread of Covid-19 (Corona Virus Disease 2019) that occurred at the end of 2019 in Wuhan China and then spread to other countries in the world turned out to have brought revolutionary changes to human interaction throughout the world. Everyone can communicate with others (both in the context of individuals with individuals, individuals with groups, groups with other groups) but cannot conduct physical meetings because of the potential to expand the spread of the virus. The solution adopted is that Physical Distancing and Social Distancing are needed so that there is no direct physical contact in meetings between individuals and social gatherings involving many people.

The organization of education was also affected by the limitation of physical contact. This then gave birth to an idea (new culture in the learning process) namely Learning from Home for students and Work From Home for Educators. So, if so far multicultural education is more focused on building students' ability to have knowledge, attitudes and skills to recognize and appreciate cultural diversity, in early 2020 there has been a cultural change in the field of education both in terms of administration and communication skills in the context of utilization digital information and communication technology as a new way to stay able to learn and carry out learning activities.

The next question, is the concept and pattern of approach in implementing multicultural education that has been carried out so far still relevant to changes occurring globally? Does the educational environment have adequate readiness and skills in responding to cultural changes and the cultural structure of educational organizations?

Multicultural education is expected to be able to present new ideas to prepare students with a new culture without leaving the noble values that have become guidelines in the life of the nation and state.

\section{RESEARCH METHODS}

The method used in this research is the Qualitative Descriptive Method which is intended to describe the challenges faced in the implementation of multicultural education in Indonesia and the expectations they have as the power to maximize the opportunities available. The data collection technique used is the Library Study, which is collecting data through printed and digital literature sources that contain information relevant to the focus of this study. Then the data are analyzed descriptively by paying attention to the truth of the information credibly and accurately.

\section{RESULT AND DISCUSSION}

The Republic of Indonesia, which consists of various ethnic groups with official cultural, linguistic and religious backgrounds since 1945, has declared its independence and demands recognition, respect and fulfillment of the rights inherent in the existence of such independence. Furthermore, efforts to fight for and form an independent, sovereign, just and prosperous nation are increasingly strengthened by the commitment to the development struggle in all fields of life.

Related to the struggle for development in the field of education, from the outset it has been stated in the Preamble of the 1945 Constitution of the Republic of Indonesia that "... to advance public welfare, develop the intellectual life of the nation, and participate in carrying out world order ...". Based on this statement it can be understood that the education sector as an effort to educate the life of the nation is given important priority to be carried out in the life of the nation and state.

Education is an integrated, holistic and comprehensive system. In Law Number 20 Year 2003 it is stated that "The National Education System is an overall component of the education component which is interrelated in an integrated manner to achieve the objectives of national education. National education is education based on Pancasila and the 1945 Constitution which is based on religious values, Indonesian national culture and responsive to changing times.

Studies on the concept of multicultural education carried out to date have been more aimed at preventing the disintegration of the nation by building awareness that differences are realities that should be understood and accepted as they are. Cultural diversity is a reality that must be accepted as the nation's cultural wealth that has been passed down by the ancestors of the Indonesian people. Therefore the concepts of multicultural education 
are always related to guidelines on the way of life of the Indonesian people.

According to reference [3] "multicultural education is the process of planting a way of life, such as respect, sincere, and tolerance of diversity of cultures that live in the midst of plural society". The concept of multicultural education is more focused on providing knowledge and skills to students to have a view or way of life that can appreciate the cultural diversity that exists in society.

Recognition and appreciation of cultural pluralism can create an open and tolerant attitude towards differences and a wise way of responding to these differences. But conditions in the current global era have shifted and present new cultures that are no longer legacies of the past, millennials are not only tolerant but then adopt any popular global culture as a new lifestyle. This is where new concepts and approaches are needed so that the adoption of a new culture will not have a negative impact on millennials today and in the future.

There are two things that are relevant to multicultural education in Indonesia, namely that in the implementation of multicultural education, the Indonesian people are actually emphasizing the recognition of the existence of a national culture that is the basis for supporting the Pancasila and the 1945 Constitution. because increasing human knowledge includes an increase in educational development.

In the implementation of multicultural education in Indonesia to date there are various challenges faced. Broadly speaking there are two challenges, namely Policy and Management. The first challenge is in terms of policy. Although in the law and a number of regulations related to education it has been stated implicitly about the importance of multicultural education, but the absence of regulations that explicitly regulate multicultural education curriculum and increasing professionalism of multicultural education teachers causes the implementation process and the results have not been maximized. Reference [4] states that in "Law Number 20 Year 2003 concerning the National Education System, the values of multicultural education are stored, but the implementation is still in a transition period to multiculturalism, because those values cannot accommodate the goals of education itself and educational institutions. national can not yet realize multicultural education. "

The second challenge is Management. When at the policy level there is still not clearly defined multicultural education at the management level at the mezzo and micro scales there will be obstacles that can weaken the implementation process. Furthermore according to reference [4] "in the learning process educators often violate the concept of cultural education". So, at the management level, every education unit starting from elementary, secondary and higher education needs a new paradigm in managing the implementation of multicultural education.

Until now the approach to implementing multicultural education in primary and secondary education units is still integrative but at the tertiary level especially in study programs such as PPKn, IPS and others, a monolithic approach has been taken as a standalone course. It aims to provide the ability of each prospective teacher to be able to teach multicultural education when they have become teachers. However, its implementation is still very general and tends to be limited to understanding multicultural education concepts.

The concept of multicultural education used to date is more focused on the concept of recognition and appreciation for the existence of cultural diversity in Indonesia in order to strengthen national unity and resilience. Even though the conditions that exist today it turns out everyone is faced with 'cultural vulnerability'. Multicultural education should be able to accommodate the relevance of education coverage with psycho-social conditions due to "cultural shock" a psycho-social vulnerability due to cultural shock that creates cultural vulnerability.

On the other hand in the midst of a difficult situation the emergence of extreme attitudes and cultural fanaticism can be one of the challenges that can hamper the objectives of the implementation of multicultural education that has been implemented. Cultural narcissism due to global social pressures has created cultural fanaticism by upholding and glorifying one's own culture so that it appears "exclusive". Domestic groups that do not understand the importance of multicultural education are a source of internal challenges; as well as other extreme groups abroad who uphold "cultural internationalization" will of course fight for a monoculture that can be created through global information and communication technology instruments. In this regard reference [1] stated that "global capitalism which is a child of neo-liberalism with the development of multinational corporation is an octopus that is pouncing on the world which will ultimately paralyze cultural plurality".

Global culture ---- which is formed in a process of globalization with its main instruments digital technology in the field of information and communication that has implications for the condition of "Bringing to the near one that far and keep that away near one". There are two sides that need to be anticipated by every teacher who conducts multicultural education, namely the formation 
of new habits in human life in today's digital era which then form a "new culture" not only in the context of communication and information but also in various aspects related to the fulfillment of every life person.

There are two keywords as a supplement in the concept of multicultural education, namely Responsive and Adaptive to global culture. The basic concept of recognition and appreciation for a culture that is different from the culture that is owned by everyone (especially educators and students) needs to be strengthened with the skills to respond and adjust wisely and smartly so that it will not create negative and detrimental things. Parents' complaints about the emergence of habits in children who live in one house but can not communicate because the child has been exposed and addicted to games and then shut themselves in a room or a certain place, is evidence of what has been stated "keep away near one". The question is how educators and parents respond to conditions like this. Are there adequate skills from parents and educators when confronted with habits which then such habits are "entrenched" among millennial generations today.

Multicultural education can be strengthened by concepts of parenting and child protection in the current digital era. Every teacher in charge and responsible for implementing multicultural education can combine the concepts, approaches and content of multicultural education with character education and the concepts of parenting and child protection in the digital age. This can be used as an opportunity that is expected to eliminate and even overcome the challenges faced in implementing multicultural education.

Furthermore, in order to guarantee the quality of the implementation of multicultural education, integrated quality management in education can also be implemented - a cohesiveness both in the concepts as explained and in the implementation of policies related to education in other relevant fields.

In developing multicultural education learning strategies there are findings in the implementation of multicultural values in schools based on Islam and Catholicism. According to reference [5] that "there are two concepts of developing multicultural education, namely" Intra-Religious Multicultural Education and Inter-religious Multicultural Humanist Education". Especially for schools organized by education units that certain religious based, the concept of multicultural development is increasingly varied. These variations arise because of the different goals and directions of multicultural education in their implementation, both intra-religious and inter-religious. About the relationship between religion and culture Paul Tillich since a few decades ago has explained about this that religious values have an influence on the cultural development of a society, and then the culture of a society can affect the religious practices of its adherents.

The concepts and approaches of inter-religious multicultural humanists are expected to create a more humanist understanding of multiculture among adherents of different religions. Religion can be a source of inspiration for a cultural life that upholds human values.

The role of educators becomes very strategic in the learning process so that they are able to explain the concepts of multicultural education that are increasingly responsive and adaptive to the development of global conditions. Culture is one important element in shaping and determining the future of students. Multicultural education is expected to be one of the solutions to maximize every potential of students to be more cultured and adapted.

\section{CONCLUSION}

Multicultural education in the era of globalization is education about the recognition and appreciation of every culture in the world in a responsive and adaptive manner. The goal of responsive and adaptive multicultural education is to instill awareness in everyone, especially students so that they have responsive and adaptive abilities in responding to a revolutionary and massive global culture. Students are given the skills to act wisely and intelligently in utilizing information and digital communication technology as part of a global culture that has "conditioned and bound" everyone to engage in it.

The challenges faced in implementing multicultural education in Indonesia today are sourced from the first, policies in the field of education that have not been able to overshadow its implementation effectively; second, management of education that has not been effective in managing multicultural education at both the macro, mezzo and micro levels; third, the unification of perceptions about concepts, approaches, strategies and content of multicultural education curriculum content; fourth, professionalism and professionalism of educators in carrying out character education; fifth, effective coordination and cooperation across sectors related both in setting policies and their implementation.

The facts show that behind the challenges faced, there are actually opportunities that are expected to be utilized to eliminate and even overcome the challenges they face. These opportunities are the future expectations, namely: first, the government's commitment to formulate responsive and adaptive policies. The policy contains concepts, approaches, strategies, content of curriculum content about multicultural education that is imperative 
and implementative; Second, there is expertise in the field of education management that can be used and utilized for multicultural education management at the level of the education unit; Third, the availability of teachers who can be trained professionally to carry out multicultural education; Fourth, the use of Indonesian human resources who are increasingly skilled in managing and utilizing information and digital communication technology.

Thus the effectiveness of implementing multicultural education can be achieved if every challenge can be overcome by maximizing every available opportunity, so that multicultural education can strengthen the character education of students who are responsive and adaptive to the global culture. Every student can have life skills in the midst of a global society, to become a generation of intelligent, superior, independent, productive and humanist.

\section{ACKNOWLEDGMENT}

The author would like to acknowledge the Rector of Manado State University in supporting the publication of this article.

\section{REFERENCES}

[1] H. A. R. Tilaar, Multikulturalisme: Tantangantantangan global masa depan dalam transformasi pendidikan nasional. Jakarta: Grasindo, 2007.

[2] T. Pangalila, 'Multikulturalisme dan Implikasinya dalam Hubungan antar Umat Bergama di Indonesia', J. Geogr. dan Pembang. Wil., vol. 5, no. 11, 2010.

[3] F. Kerebungu, T. Pangalila, and M. Umar, 'The Importance Of Multicultural Education As An Effort Towards Indonesian National Awareness', in 2nd International Conference on Social Science (ICSS 2019), 2019, vol. 383, no. Icss, pp. 797-800.

[4] T. Nur Afidah, 'Konsep dan Paradigma Pendidikan Multikultural (Studi Analisis Undang-Undang Republik Indonesia Nomor 20 Tahun 2003 Tentang Sistem Pendidikan Nasional)'. University of Muhammadiyah Malang, 2007.

[5] M. Rohman, 'Implementasi Nilai-Nilai Multikultural di MAN Yogyakarta III dan SMA Stella Duce 2 Yogyakarta', UIN Sunan Kalijaga Yogyakarta, 2016. 